\title{
Two families in Sri Lanka with southeast Asian ovalocytosis
}

\section{HMS Vidyatilake ${ }^{1}$ and LV Gooneratne ${ }^{2}$}

(Index words: Autosomal dominant, band 3, hyperstable, malaria, ovalocytes)

\section{Introduction}

Inherited defects of the red cell membrane which lead to abnormal red cell morphology, indices and osmotic fragility are not uncommon. Some defects cause clinically significant haemolysis whereas others run a relatively benign course. This paper emphasises the importance of

${ }^{1}$ Haematologist and ${ }^{2}$ Registrar in Haematology, Lady Ridgeway Children's Hospital, Colombo 8, Sri Lanka.

Correspondence: HMSV, Tel: +94 11 2696643, e-mail: drsdharma@sltnet.lk (Competing interests: none declared).

Received 29 April and revised version accepted 30 October 2003. 
being aware of one such benign disorder. Southeast Asian ovalocytosis (SAO), also known as stomatocytic elliptocytosis of Melanesians, has a unique red cell morphology in the blood film [1]. It is most commonly seen among Melanesians in Papua New Guinea, in some population groups in Indonesia and Malaysia, and in Malaysian aboriginals [2,3,4]. We report two families with SAO in Sri Lanka.

\section{Case 1}

A 7-year old boy was admitted to the Lady Ridgeway Hospital with a viral fever. A blood picture done as a preliminary investigation showed over $30 \%$ of the red cells to be large ovalocytes with some showing a central slit or transverse ridge. These features are characteristic of SAO. Screening of family members revealed similar features in the blood picture of his sister (only sibling), father and paternal grandmother whose father was an immigrant from Malaysia (Figure 1, Table 1). The blood picture of the boy's mother was normal. There was no evidence of haemolysis in any of the affected members.



Figure 1. Family tree of the first case.

Table 1. Comparison of red cell indices of family members of first case

An increase in the variation of red cell size is indicated by a high red cell distribution width or RDW (normal < 13.2\%), which is probably due to the ovalocytes.

\begin{tabular}{lcccl}
\hline & $\begin{array}{c}\text { Age } \\
\text { (years) }\end{array}$ & $\begin{array}{c}R B C \\
\left(\times 10^{12} / L\right)\end{array}$ & $\begin{array}{c}H b \\
(g / d L)\end{array}$ & $\begin{array}{l}R D W \\
(\%)\end{array}$ \\
\hline Proband & 7 & 4.65 & 12.9 & 14.2 (high) \\
Sister & 3 & 4.41 & 12.6 & 13.8 (high) \\
Father & 37 & 4.71 & 14.9 & 15.3 (high) \\
Mother & 36 & 4.78 & 13.7 & 12.0 \\
Grandmother & 65 & 3.7 & 12.1 & 14.6 (high) \\
\hline
\end{tabular}

$\mathrm{Hb}=$ haemoglobin, $\mathrm{RBC}=$ red blood (cell) count, $\mathrm{RDW}=$ red cell distribution width

\section{Case 2}

A 30-month old boy had been investigated for a haemolytic anaemia since birth at Base Hospital, Horana. He was pale, icteric and had hepatosplenomegaly with a haemoglobin of $6.5 \mathrm{~g} / \mathrm{dL}$, a reticulocyte count of $10.5 \%$ and a serum bilirubin of $170 \mu \mathrm{mol} / \mathrm{L}$. The blood picture showed red cells which were markedly hypochromic and microcytic, a population of large ovalocytes, some with central ridges, polychromasia and normoblastaemia. The white cells and platelets were normal. Haemoglobin electrophoresis and alkaline denaturation test $(\mathrm{HbF}$ $21.3 \%$ ) confirmed that he had beta thalassaemia major together with features characteristic of SAO. As he was the only live child, his parents were screened for both conditions. His father, a Sinhalese from Anuradhapura was found to have a beta thalassaemia trait $\left(\mathrm{HbA}_{2}-5.8 \%\right)$ with SAO. His mother a Sinhalese from Kurunegala had a beta thalassaemia trait $\left(\mathrm{HbA}_{2}-5.1 \%\right)$ with no evidence of SAO (Figure 2, Table 2).

The child is being managed with on demand blood transfusions and parenteral iron chelation therapy.

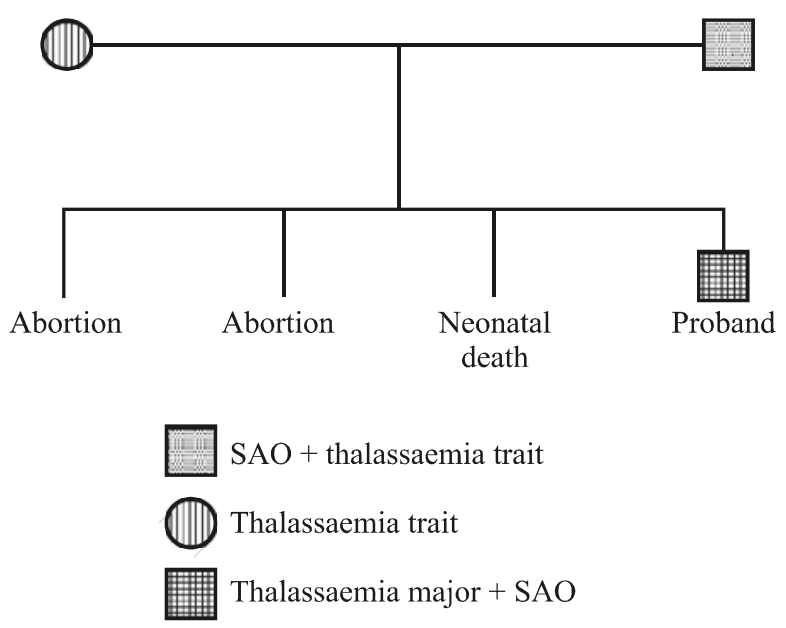

Figure 2. Family tree of the second case.

\section{Discussion}

Southeast Asian ovalocytosis has an autosomal dominant inheritance. It results in red cells that are rigid and hyperstable (rather than unstable) giving rise to the unique red cell morphology [2]. The red cell membrane is composed of a phospholipid and cholesterol bilayer and a number of membrane protiens. These proteins have been categorised as integral membrane proteins and peripheral membrane proteins, and assigned specific names. These are based on the mobility of each protein on a sodium dodecyl sulphate polyacrylamide gel electrophoresis.

The protein that is defective in $\mathrm{SAO}$ (anion exchanger 1 ) is identified on band 3 when stained with Coomassie brilliant blue stain [5]. Two mutations that cause abnormalities in the band 3 protein have been identified 
Table 2. Comparison of red cell indices (*Proband was after blood transfusion)

The low indices of the father and mother of this child are consistent with thalassaemia minor. The significant elevation of the father's RDW is compatible with the presence of large ovalocytes.

\begin{tabular}{lccccccc}
\hline & Age (years) & $H b(g / d L)$ & $R B C\left(\times 10^{12} / L\right)$ & $M C V(f L)$ & $M C H(p g)$ & $M C H C(g / d L)$ & $R D W(\%)$ \\
\hline Proband* & 2.5 & 9.5 & 3.2 & 81.6 & 29.8 & 35.8 & 12.0 \\
Father & 38 & 9.8 & 4.27 & 77.0 & $22.9(\mathrm{~L})$ & 29.8 & $16.6(\mathrm{H})$ \\
Mother & 32 & 8.5 & 4.05 & $69(\mathrm{~L})$ & $21.0(\mathrm{~L})$ & 30.4 & $14.5(\mathrm{H})$ \\
\hline
\end{tabular}

$\mathrm{H}=$ High, $\mathrm{L}=$ Low, $\mathrm{Hb}=$ haemoglobin, $\mathrm{MCH}=$ mean corpuscular haemoglobin, $\mathrm{MCHC}=$ mean corpuscular haemoglobin concentration, $\mathrm{MCV}=$ mean corpuscular volume, $\mathrm{RBC}=$ red blood (cell) count, $\mathrm{RDW}=$ red cell distribution width

in patients with SAO. Homozygosity for these mutations are thought to lead to embryonic lethality while the heterozygous state results in the formation of abnormal erythrocytes which exhibit increased binding of band 3 protein to Ankyrin (band 2.1 protein), increased tyrosine phophorylation of band 3 protein, inability to transport sulfate anions and a markedly restricted lateral and rotational mobility [2,3]. Other abnormalities associated with SAO are reduced osmotic fragility of red cells, resistance to shape change by echinocytic agents and a reduced expression of many red cell antigens.

Another remarkable feature of SAO erythrocytes is their resistance to invasion by several strains of malarial parasites, including Plasmodium falciparum and $P$. knowlesi, particularly against heavy infections and cerebral malaria [2,3]. Band 3 serves as one of the receptors for the malarial parasite, as evidenced by inhibition of invasion in vitro [2]. The abnormal band 3 protein may not function as a receptor for the malarial parasite.

The diagnosis of SAO can be made accurately on a blood film stained with Romonowsky stain [6,7]. The finding of $30 \%$ or more of oval shaped red cells with stomatocytes, with a notable absence of clinical and laboratory evidence of anaemia and haemolysis is highly suggestive [2]. There is also a minor population of macroovalocytes, many of which are stomatocytic. The stoma is two in each cell. It may be longitudinal, transverse, Vshaped or Y-shaped [1]. The haemoglobin, mean corpuscular value (MCV), mean corpuscular haemoglobin $(\mathrm{MCH})$, mean corpuscular haemoglobin concentration (MCHC) and the reticulocyte count are normal. A useful screening test is the demonstration of the resistance of ovalocytes or their ghosts to changes in shape produced by treatment that produces spiculation in normal cells, such as overnight incubation of red cells [2]. Rapid genetic diagnosis can be made by demonstrating a shorter band (27 base pair deletion) compared to a normal control [2,7].

\section{Conclusion}

Diagnosis of SAO can be made on a blood picture or by DNA analysis. Awareness of the presence of this red cell disorder in Sri Lanka, with a multi-racial population and possible preservation of the gene in areas endemic for malaria, is important.

\section{References}

1. Bain BJ. Blood Cells: A Practical Guide. 2nd edn. Oxford: Blackwell Science, 1995.

2. Gallagher PG, Forget BG. Hereditary spherocytosis, elliptocytosis and related disorders. In: Beutler E, Lichtman MA, Coller BS, Kipps TJ, Seligsohn U, eds. Hematology. New York: McGraw Hill, 2001: 515-6.

3. Luzzatto L, Gordon-Smith EC. Inherited haemolytic anaemias. In: Hoffbrand AV, Lewis SM, Tudenham EG, eds. Postgraduate Haematology. Oxford: ButterworthHeinemann, 1999: 133-52.

4. Bruce LJ, Wrong O, Toye AM, Young MT, Ogle G. Band 3 mutaion, renal tubular acidosis and South-East Asian ovalocytosis in Malaysia and Papua New Guinea. Biochemical Journal 2000; 350: 41-51.

5. Wrong O, Bruce LJ, Unwin RJ, Toye AM, Tanner MJ. Band 3 mutations, distal renal tubular acidosis, and Southeast Asian ovalocytosis. Kidney International 2002; 62: 10-9.

6. Sapak P, Sleigh A, Williams G, Peter W, Ginny M, et al. Measurement of ovalocyte frequency in peripheral blood smears in defining ovalocytosis in Papua New Guinea. Tropical Medicine and International Health 1998; 3: 809-17.

7. Mgone CS, Genton B, Peter W, Paniu MM, Alpers MP. The correlation between microscopical examination and erythrocyte band 3 (AE1) gene deletion in South-east Asian ovalocytosis. Transactions of the Royal Society of Tropical Medicine and Hygiene 1998; 92: 296-9. 